\title{
Analisis Lingkungan Kerja dan Karakteristik Pekerja Terhadap Faal Paru Pekerja Industri Papan Semen Rata (Studi Kasus di PT “ $X$ ” Malang)
}

\author{
Amelia Nurridha Putri ${ }^{1}$, Febri Endra Budi Setyawan ${ }^{1}$, Abi Noerwahjono ${ }^{1}$. \\ ${ }^{1}$ Pendidikan dokter, Fakultas Kedokteran,Universitas Muhammadiyah Malang \\ Jl. Bendungan Sutami 188 A Malang, 65145 \\ Email: amelianurridha@gmail.com
}

\begin{abstract}
ABSTRAK
Penyakit Akibat Kerja (PAK) merupakan masalah kesehatan akibat kerja, khususnya pada perusahaan industri. Kasus PAK di dunia tercatat lebih dari $30 \%$ PAK merupakan penyakit paru. Penurunan faal paru dapat diakibatkan oleh beberapa faktor terutama pada pekerja industri. Faktor yang mempengaruhi penurunan faal paru diantaranya adalah lingkungan kerja dan karakteristik pekerja. Menganalisis lingkungan kerja dan karakteristik pekerja terhadap faal paru pekerja industri papan semen rata di PT " $\mathrm{X}$ " Malang. Observasional, Pendekatan Cross Sectional, Total Sampling. Hasil penelitian menunjukkan bahwa pekerja yang memiliki gangguan faal paru sebanyak 202 pekerja (71\%), 68\% diantaranya mengalami gangguan faal paru tipe restriktif dan 3\% mengalami obstruktif. Faktor-faktor yang berpengaruh terhadap faal paru berdasarkan uji korelasi adalah status gizi, kebiasaan olahraga, kebiasaan merokok, penggunaan APD saat bekerja dan riwayat pekerjaan sebelumnya di bidang industri dengan $p$ value $<0,05$. Sehingga hasil analisis uji statistik yang telah dilakukan membuktikan adanya pengaruh yang signifikan antara lingkungan kerja dan karakteristik pekerja terhadap faal paru pekerja industri papan semen rata di PT "X" Malang. Status gizi, kebiasaan olahraga, kebiasaan merokok, penggunaan APD (masker) dan riwayat pekerjaan sebelumnya di bidang industri berpengaruh terhadap faal paru pekerja industri papan semen rata di PT "X" Malang.
\end{abstract}

Kata Kunci: PAK, Gangguan Faal Paru, Pekerja Industri, Lingkungan Kerja, Karakteristik Pekerja

\begin{abstract}
Occupational Disease is a work-related health problem, especially in industrial companies. Lung disease accounted for more than $30 \%$ of all Occupational Disease cases in the world. Decrease in lung physiology can be caused by several factors, especially in industrial workers. Factors affecting decrement of pulmonary function includes work environment and worker characteristics. To analyse work environment and worker characteristics on pulmonary function of partition board industrial worker at PT " $\mathrm{X}$ " Malang. Observational, Cross Sectional approach, Total Sampling. The results showed that workers with pulmonary function failure were 202 workers (71\%), 68\% of whom had restrictive lung- type lung disorders and 3\% obstructive. Factors influencing lung physiology based on correlation test are nutritional status, sport habit, smoking habit, use of PPE at work and previous work history in industry with $\mathrm{p}$ value $<0,05$. Result of statistical test analysis that has been done shows significant influence between work environment and worker characteristic to pulmonary function of partition board industrial average workers in PT " $\mathrm{X}$ " Malang. Nutritional status, sport habit, smoking habit, use of PPE (mask) and previous work history in industrial affects the lung physique of partition board industrial workers in PT "X" Malang.
\end{abstract}

Keyword : Occupational Disease, Pulmonary Function, Partition Board Industrial Worker, Work Environment, Worker Characteristics 


\section{PENDAHULUAN}

Tenaga kerja memegang peranan penting dalam proses pembangunan industri, sehingga memerlukan perhatian khusus baik kemampuan, keselamatan maupun kesehatan kerja. Keselamatan dan kesehatan kerja (K3) merupakan suatu upaya untuk menciptakan suasana kerja yang aman, nyaman dan dapat meningkatkan produktivitas ${ }^{1}$. Sebagian dari tenaga kerja menyadari bahwa terdapat kemungkinan pekerjaan dapat menimbulkan penyakit, tetapi banyak juga yang tidak menyadari jika pekerjaan adalah salah satu faktor penyebab penyakit tertentu ${ }^{2}$.

Faktor yang dapat mempengaruhi penyebab penyakit atau gangguan pada saluran pernapasan akibat debu, yaitu individu dan lingkungan. Faktor individu meliputi umur, jenis kelamin, status gizi, mekanisme pertahanan paru, faktor imunologis, anatomi dan fisiologi saluran pernapasan serta kebiasaan merokok. Faktor lingkungan yaitu sumber paparan/jenis pabrik, lamanya paparan, penggunaan Alat Pelindung Diri (APD) dan prinsip ergonomic ${ }^{3}$.

Dalam lingkungan kerja yang berdebu, masa kerja dapat mempengaruhi dan menurunkan kapasitas fungsi paru pada pekerja ${ }^{4}$. Masa kerja > 5 tahun potensial mendapat gangguan kapasitas vital paru sebesar 8 kali lebih besar dibandingkan dengan masa kerja $<5$ tahun ${ }^{5}$. Sedangkan, lama kerja adalah waktu yang dihabiskan seseorang berada dalam lingkungan kerja dalam waktu sehari. Data jumlah jam kerja per minggu pada aktivitas pekerja yang terpapar debu dapat digunakan sebagai perkiraan kumulatif paparan yang diterima oleh seorang pekerja. Paparan dengan konsentrasi rendah dalam waktu yang lama mungkin tidak akan segera menunjukkan nilai penurunan kualitas vital paru dibandingkan dengan paparan tinggi dengan waktu yang singkat ${ }^{6}$

$$
\text { Indonesia merupakan negara }
$$

terbesar ke-8 sebagai importir, prosesor, konsumer serta eksporter asbes dan materialnya. Salah satu industri papan semen rata yang berkembang adalah PT "X" Malang yang berdiri pada tahun 2012. Berdasarkan data primer pekerja yang bekerja di perusahaan tersebut sekitar 350 pekerja, 23 orang diantaranya telah dilakukan pemeriksaan spirometri untuk menilai faal paru dan didapatkan hasil bahwa $23 \%$ pekerja mengalami gangguan faal paru tipe restriktif moderate. Perusahaan tersebut memproduksi lembaran serat krisotil semen yang digunakan sebagai pengganti dinding pertisi maupun plafon. Bahan yang digunakan untuk membuat papan semen rata adalah asbes $^{7}$.

Asbes merupakan batuan yang padat, namun sangat mudah untuk dipisah-pisahkan menjadi serat-serat halus yang umumnya sangat ringan dan mudah terbang. Bahan dasar untuk pembuatan produk-produk asbes merupakan bahan 
tambang yang mengandung unsur-unsur radioaktif alamiah yang selalu berada dalam bentuk gas dan terlarut dalam udara ${ }^{8}$

Asbestosis merupakan salah satu PAK yang disebabkan oleh paparan serat asbes dalam jangka waktu lama. Gejala yang akan timbul salah satunya adalah alveolitis dan fibrosis paru yang dapat mengakibatkan penurunan kapasitas paru, sehingga paru-paru sulit mengembang.

Kelainan tersebut merupakan tipe kelainan restriktif $^{8}$. Berdasarkan keterangan diatas, peneliti mencoba untuk menganalisis lingkungan kerja dan karakteristik pekerja terhadap faal paru pekerja industri papan semen rata di PT "X" Malang.

\section{METODE PENELITIAN}

Penelitian ini menggunakan metode penelitian observasional analitik dengan pendekatan cross sectional. Data dikumpulkan dengan metode kuantitatif dan kualitatif, yaitu survey dengan kuesioner dan pemeriksaan dengan spirometri. Pengambilan data ini dilakukan langsung di tempat penelitian oleh responden penelitian.

Responden penelitian berasal dari pekerja PT "X" Malang. Teknik yang dipakai pada penelitian ini adalah total sampling dimana jumlah sampel yang diambil sama dengan populasi. Secara umum, jumlah total populasi adalah 350 pekerja. Kriteria inklusi merupakan semua pekerja yang bekerja di PT "X"
Malang, tidak cuti saat penelitian berlangsung, tidak dalam kondisi sakit dan bersedia ikut berpartisipasi dalam penelitian. Kriteria eksklusi pekerja yang memiliki RPD saluran pernapasan dan riwayat pekerjaan sebelumnya di bidang industri. Variabel bebas pada penelitian ini adalah lingkungan kerja dan karakteristik pekerja. Variabel terikat pada penelitian ini adalah faal paru pekerja. Instrumen yang dipergunakan dalam penelitian ini ada 2.

a. Instrumen satu berupa kuisioner yang berisi tentang lingkungan kerja yaitu masa kerja dan lama kerja dan karakteristik pekerja yaitu usia, jenis kelamin, BB, TB, kebiasaan olahraga, kebiasaan merokok, penggunaan APD, RPD saluran pernafasan, riwayat pekerjaan sebelumnya dan pekerjaan lain dibidang industri

b. Instrumen dua berupa pemeriksaan faal paru dengan menggunakan spirometri yang dapat dilihat dari hasil FVC $<$ FEV1 dan \%FEV1/FVC.

Analisis data yang dilakukan peneliti adalah analisa Univariat dengan tujuan untuk melihat sebaran distribusi frekuensi masing-masing variabel. Peneliti akan melakukan analisa bivariat yang bertujuan untuk mengetahui adanya hubungan digunakan uji Lambda. Peneliti akan melakukan analisa multivariat untuk menjelaskan pengaruh masingmasing subvariabel dengan menggunakan uji regresi logistik. 


\section{HASIL PENELITIAN}

Pada penelitian didapatkan 286 sampel yang memenuhi kriteria inklusi dan tidak drop out.

\begin{tabular}{llll}
\hline \multicolumn{1}{c}{ Variabel } & Klasifikasi & Frekuensi & \multicolumn{1}{c}{$\%$} \\
\hline Jenis & Laki-laki & 254 & 89 \\
kelamin & Perempuan & 32 & 11 \\
Usia & <30 tahun & 117 & 41 \\
& $>30$ tahun & 169 & 59 \\
Status Gizi & Normal & 196 & 68.5 \\
& Tidak & 90 & 31.5 \\
& Normal & & \\
Kebiasaan & Ya & 106 & 37 \\
Olahraga & Tidak & 180 & 63 \\
Kebiasaan & Tidak & 124 & 43 \\
Merokok & & & \\
Penggunaan & Ya & 162 & 57 \\
APD & Ya & 256 & 89.5 \\
(masker) & & & \\
RPD saluran & Tidak & 30 & 10.5 \\
Pernafasan & Tidak & 286 & 100 \\
Pekerjaan & Ya & 0 & 0 \\
Sebelumnya & Tidak & 238 & 83 \\
di bidang & & & \\
Industri & Ya & 48 & 17 \\
Pekerjaan & Tidak & 276 & 96.5 \\
sampingan & & & \\
$\begin{array}{l}\text { Dibidang } \\
\text { Industri }\end{array}$ & Ya & 10 & 3.5 \\
\hline
\end{tabular}

Berdasarkan hasil penelitian, diperoleh informasi pada variabel karakteristik pekerja bahwa dari 202 pekerja jumlah populasi pekerja laki-laki (89\%) lebih banyak daripada perempuan (11\%), dapat dilihat pada tabel diatas (tabel 5.1). Berdasarkan hasil penelitian pada pekerja PT "X" Malang didapatkan responden yang berusia $\geq 30$ tahun (59\%) lebih banyak daripada $<30$ tahun dapat dilihat pada tabel diatas (tabel 5.1).

Dari 286 responden, 196 diantaranya memiliki status gizi normal dan 90 orang memiliki status gizi kurang atau lebih. Rata-rata pekerja di perusahaan tersebut $63 \%$ tidak melakukan olahraga pada setiap minggunya dan $57 \%$ pekerja memiliki kebiasaan merokok \pm 1-3 pack per harinya. Penggunaan APD (masker) saat bekerja di PT "X" Malang sudah cukup bagus, $89.5 \%$ pekerja selalu menggunakan masker saat bekerja. Pada tabel 5.1 dapat dilihat bahwa pekerja PT "X" Malang 96.5\& tidak memiliki pekerjaan lain selain diperusahaan tersebut dan $83 \%$ pekerja belum pernah bekerja di perusahaan industri sebelumnya.

\begin{tabular}{cccc}
\hline Variabel & Klasifikasi & Frekuensi & $\%$ \\
\hline Ventilasi & Ada & 286 & 100 \\
& Tidak ada & 0 & 0 \\
Masa kerja & $<5$ tahun & 222 & 78 \\
& $>5$ tahun & 64 & 22 \\
Lama kerja & $<8$ jam & 149 & 52 \\
& $>8$ jam & 137 & 48 \\
\hline
\end{tabular}

Berdasarkan hasil penelitian, diperoleh informasi pada variabel lingkungan kerja bahwa dari 202 pekerja didapatkan 78\% pekerja PT "X” Malang bekerja selama $<5$ tahun dengan lama kerja $<8$ $\operatorname{jam}(52 \%)$.

\begin{tabular}{clcc}
\hline Variabel & Klasifikasi & Frekuensi & \% \\
\hline Faal Paru & $\begin{array}{l}\text { Tidak ada } \\
\text { gangguan }\end{array}$ & 84 & 29 \\
\hline & $\begin{array}{l}\text { Ada } \\
\text { gangguan }\end{array}$ & 202 & 71 \\
\hline
\end{tabular}

Berdasarkan hasil penelitian, diperoleh informasi pada variabel lingkungan kerja bahwa dari 202 pekerja didapatkan sejumlah 202 responden (71\%) didapatkan gambaran faal paru yang tidak normal. Identifikasi faal paru pada pekerja PT "X" Malang dapat dijelaskan sebagi berikut: 


\begin{tabular}{cccc}
\hline Variabel & Klasifikasi & Frekuensi & \% \\
\hline & Normal & 84 & 29
\end{tabular}

\section{Faal Paru}

\begin{tabular}{ccc}
\hline Restriktif & 194 & 68 \\
\hline Obstruktif & 8 & 3
\end{tabular}

Dari 202 pekerja yang mengalami gangguan faal paru 194 diantaranya mengalami gangguan tipe restriktif dan 8 pekerja dengan tipe obstruktif.

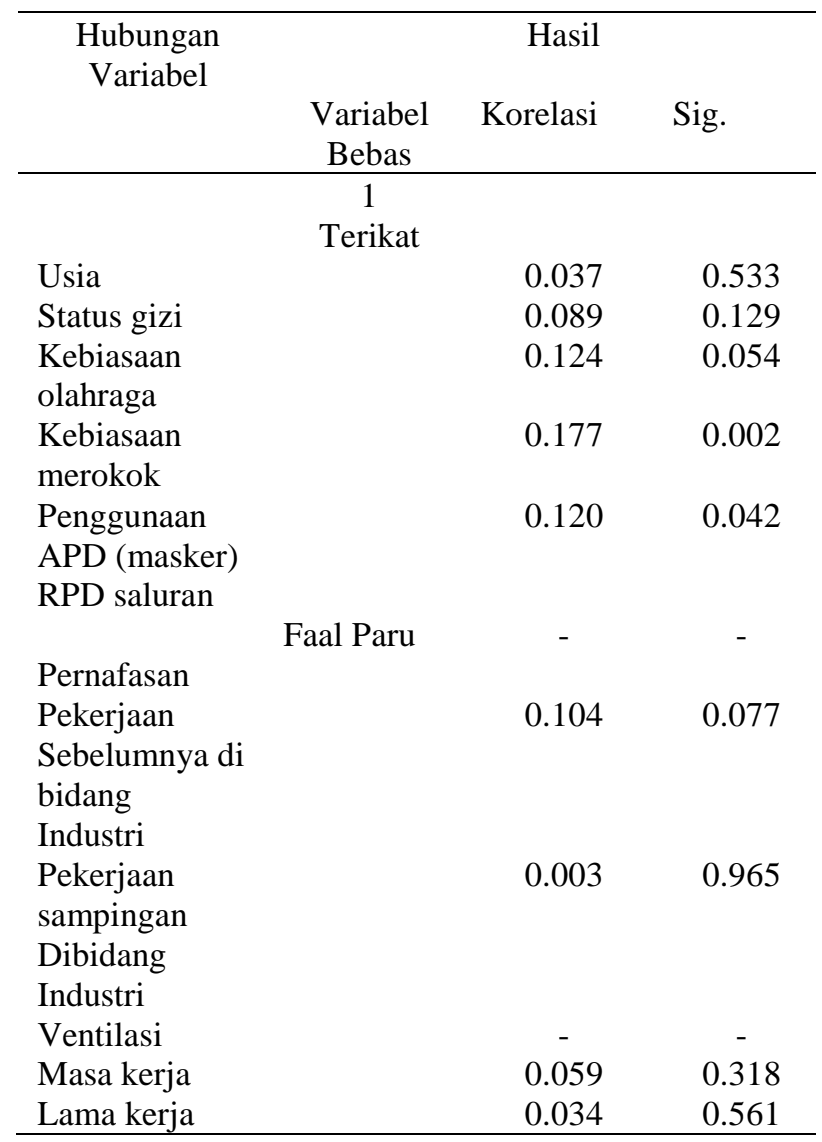

\section{PEMBAHASAN}

Hasil uji bivariat dengan menggunakan lambda menunjukkan adanya hubungan antara variabel bebas terhadap variabel terikat.

Pada variabel kebiasaan olahraga, kebiasaan merokok dan penggunaan APD khususnya masker didapatkan

$\mathrm{p}$ value $<0,005$ mengartikan bahwa terdapat hubungan yang signifikan terhadap faal paru.

\begin{tabular}{lcc}
\hline \multicolumn{1}{c}{ Variabel } & Hasil regresi & $\%$ \\
\hline Jenis kelamin & 2.098 & 0.150 \\
Usia & 0.651 & 0.144 \\
Status Gizi & 2.104 & 0.021 \\
Kebiasaan olahraga & 1.986 & 0.021 \\
Kebiasaan merokok & 3.002 & 0.000 \\
Penggunaan & 3.455 & 0.032 \\
APD (masker) & & \\
RPD saluran & - & - \\
Pernafasan & & \\
Pekerjaan & 2.470 & 0.032 \\
Sebelumnya di & & \\
bidang & & \\
Industri & & \\
Pekerjaan & 0.836 & 0.813 \\
sampingan & & \\
Dibidang Industri & & - \\
Ventilasi & - & 0.439 \\
Masa kerja & 0.775 & 0.797 \\
Lama kerja & 0.927 & \\
\hline
\end{tabular}

Hasil uji regresi logistik didapatkan p value <

0,005 pada variabel status gizi, kebiasaan olahraga,

kebiasaan merokok, penggunaan APD khususnya masker dan riwayat pekerjaan sebelumnya di bidang industri, mengartikan bahwa signifikan mempengaruhi faal paru.

Jumlah total pekerja di PT " $\mathrm{X}$ " Malang sejumlah 350 pekerja dan yang termasuk dalam kriteria inklusi dan tidak drop out sebanyak 286. Faktor-faktor yang berhubungan dengan gangguan faal paru meliputi : ventilasi ruang kerja, masa kerja, lama kerja, jenis kelamin, usia, status gizi, kebiasaan olahraga, kebiasaan merokok, penggunaan APD (masker), RPD saluran pernapasan, riwayat pekerjaan sebelumnya dan pekerjaan sampingan di bidang industri. 
Pada penelitian ini terdapat tiga variabel pada lingkungan kerja yaitu ventilasi ruang kerja, masa kerja dan lama kerja pada pekerja PT “X” Malang.

Berdasarkan data dari hasil penelitian analisis univariat pekerja PT "X” Malang didapatkan rata-rata pekerja dengan masa kerja $<5$ tahun sejumlah 222 orang $(78 \%)$ lebih banyak dibanding dengan masa kerja $\geq 5$ tahun sejumlah 64 responden (22\%). Hal ini dapat dikarenakan PT "X" Malang baru berdiri tahun 2012.

Variabel lama kerja pada pekerja papan semen rata di PT “X” Malang didapatkan sejumlah 149 responden $(52 \%)$ bekerja selama $<8$ jam setiap hari dan 137 responden (48\%) bekerja $\geq 8$ jam. Hal ini dikarenkan PT "X" Malang menggunakan sistem pergantian shift.

Pada variabel ventilasi ruang kerja didapatkan $100 \%$ responden memiliki ruang kerja dengan ventilasi yang cukup baik, yaitu pintu besar yang terbuka dan terpasang alat exchaust and supply system. Penelitian ini sejalan dengan teori yang dikemukakan oleh Talty T John, Dalam kondisi panas, udara akan memuai dan naik lalu keluar melalui ventilasi udara di atap. Lalu akan diganti dengan udara yang segar melalui lubang ruangan seperti jendela dan pintu yang terbuka. Pertukaran udara juga dapat dilakukan dengan cara memasang sistem pengeluaran udara (exchaust system) dan pemasukan udara (supply system) dengan menggunakan fan ${ }^{5}$.
Berdasarkan pengambilan sampling pada penelitian ini didapatkan sebaran jenis kelamin dari 286 responden $89 \%$ pekerja PT "X" Malang adalah laki-laki sejumlah 254 orang dan 32 orang (11\%) adalah perempuan dengan mayoritas pekerja berusia 230 tahun yaitu sebanyak 169 orang.

Berdasarkan data dari hasil penelitian ini didapatkan bahwa pada pekerja PT "X" Malang mayoritas memiliki staus gizi baik atau normal sejumlah 196 orang $(68,5 \%)$ responden dan 90 orang $(31,5 \%)$ memiliki status gizi kurang atau lebih. Variabel status gizi merupakan salah satu variabel bebas yang signifikan mempengaruhi faal paru. Penelitian ini tidak sejalan dengan penelitian yang dilakukan oleh Budiono (2007) yang menunjukkan tidak adanya pengaruh antara status gizi dengan faal paru pada pekerja di Semarang . Sama halnya dengan penelitian yang dilakukan oleh Khumaidah (2009) pada pekerja mebel di Jepara menunjukkan tidak terdapat pengaruh antara status gizi dengan faal paru ${ }^{9}$

Akan tetapi, hasil penelitian ini sejalan dengan teori yang menyatakan bahwa kekurangan makanan yang terus menerus akan menyebabkan susunan fisiologis terganggu dan dapat mengganggu kapasitas vital seseorang . Kesehatan dan daya kerja sangat erat hubungannya dengan tingkat gizi seseorang. Tubuh memerlukan zat-zat dari makanan untuk pemeliharaan tubuh, perbaikan 
kerusakan-kerusakan dari sel dan jaringan dan untuk pertumbuhan, yang banyak sedikitnya keperluan ini sangat bergantung kepada usia, jenis kelamin, lingkungan dan beban kerja yang dimiliki oleh seseorang ${ }^{6}$.

Status gizi kurang dapat berakibat pada turunnya sel perantara imunitas yang dapat meningkatkan kerentanan terhadap infeksi. Sedangkan pada status gizi yang berlebih dengan adanya timbunan lemak dapat menurunkan complience paru sehingga ventilasi paru akan terganggu akibatnya faal paru akan menurun ${ }^{10}$.

Sel imunitas pada saluran pernafasan diperankan oleh Limfosit $\mathrm{T}$ yang dapat membunuh, mengisolasi dan menggumpalkan benda asing yang masuk. Pada pekerja yang terkena paparan debu dan akibat dari turunnya sel perantara imunitas maka limfosit T tidak dapat membentuk pertahanan terhadap debu atau partikel yang masuk ke dalam saluran pernafasan akibatnya debu atau partikel yang masuk ke dalam saluran nafas dapat mancapai paru ${ }^{10}$. Debu yang mencapai saluran nafas bawah merangsang suatu reaksi peradangan- imun yang menyebabkan akumulasi makrofag yang berisi debu sehingga akhirnya terjadi fibrosis paru. Akibat fibrosis, paru menjadi kaku sehingga membatasi compliance atau daya pengembangan paru ${ }^{10}$.

Berdasarkan data dari hasil penelitian ini didapatkan bahwa pada pekerja PT "X"
Malang mayoritas tidak memiliki kebiasaan berolahraga pada tiap minggunya sejumlah 180 orang (63\%) responden dan 106 orang (37\%) memiliki kebiasaan olahraga 2-3x dalam seminggu. Pada variabel kebiasaan olahraga memiliki hubungan yang signifikan terhadap faal paru karena diketahui bahwa pekerja yang tidak memiliki kebiasaan olahraga berisiko terhadap gangguan faal paru sebesar 2 kali lebih tinggi dari pekerja yang memiliki kebiasaan olahraga 2-3x seminggu. Penelitian ini sejalan dengan teori yang menyatakan bahwa olahraga yang teratur akan meningkatkan kemampuan pernapasan dan mempengaruhi organ tubuh hingga kerja organ lebih efisien dan kapasitas fungsi paru bekerja maksimal. Olahraga dapat meningkatkan aliran darah melalui paru-paru sehingga menyebabkan $\mathrm{O} 2$ dapat berdifusi ke dalam kapiler paru dengan volume yang lebih besar atau maksimum. Teori tersebut sejalan dengan penelitian ini dimana pekerja yang tidak pernah atau jarang melakukan olahraga pada setiap minggunya memiliki potensi terhadap gangguan faal paru lebih besar dibandingkan dengan pekerja yang memiliki kebiasaan berolahraga minimal 2-3x dalam seminggu ${ }^{11}$.

Berdasarkan data dari hasil penelitian ini didapatkan bahwa pada pekerja PT "X" Malang mayoritas memiliki kebiasaan merokok sejumlah 162 orang (57\%) dan yang tidak memiliki kebiasaan merokok sejumlah 124 orang (43\%). Dari hasil 
analisis uji bivariat didapatkan hubungan antara kebiasaan merokok dengan faal paru pada pekerja di PT "X" Malang. Hasil ini sesuai dengan penelitian yang dilakukan Eva (2013) yang menunjukkan adanya hubungan antara variabel kebiasaan merokok dengan faal paru pada pekerja Industri Genteng Kabupaten Kebumen ${ }^{12}$. Demikian pula pada penelitian Rasyid (2013) yang menunjukkan adanya hubungan antara variabel kebiasaan merokok dengan faal paru pada pekerja industri percetakan dengan frekuensi $94,3 \%$ pekerja yang memiliki kebiasaan merokok terdapat gangguan pada gambaran faal paru $^{13}$.

Gangguan faal paru yang dialami oleh individu dapat dipengaruhi oleh beberapa hal, diantaranya adalah merokok. Rokok yang dikonsumsi setiap harinya mengandung beberapa senyawa yang dapat membahayakan kondisi paru individu. Senyawa tersebut dapat mengendap dalam paru dan dapat menimbulkan perubahan fisiologi paru. Senyawa tersebut diantaranya adalah nikotin, karbon monoksida dan tar. Terdapat beberapa alasan yang mendasari pernyataan ini ${ }^{14}$.

Pertama, salah satu efek dari penggunaan nikotin akan menyebabkan konstriksi bronkiolus terminal paru, yang meningkatkan resistensi aliran udara ke dalam dan keluar paru. Kedua, efek iritasi asap rokok menyebabkan peningkatan sekresi cairan ke dalam cabang-cabang bronkus serta pembengkakan lapisan epitel. Ketiga, nikotin dapat melumpuhkan silia pada permukaan sel epitel pernapasan yang secara normal terus bergerak untuk memindahkan kelebihan cairan dan partikel asing dari saluran pernafasan. Akibatnya lebih banyak debris berakumulasi dalam jalan napas dan kesukaran bernapas menjadi semakin bertambah ${ }^{14}$.

Menurut American Thoracic Society (2012) kebiasaan merokok dapat menyebabkan gangguan faal paru tipe obstruktif, khususnya pada COPD oleh karena pajanan yang terus menerus dan berlangsung lama dengan asap rokok dapat menyebabkan gangguan dan perubahan mukosa jalan napas ${ }^{15}$

Berdasarkan data dari hasil penelitian ini didapatkan bahwa mayoritas pekerja pada PT "X" Malang memakai APD khususnya masker saat bekerja terdapat sejumlah 256 orang $(89,5 \%)$ sedangkan 30 orang $(10,5 \%)$ lainnya tidak pernah atau jarang untuk memakai masker saat bekerja. Hasil uji analisis bivariat menunjukkan bahwa ada hubungan antara penggunaan APD (masker) dengan faal paru pada pekerja PT " $\mathrm{X}$ " Malang. Penelitian ini sejalan dengan penelitian Armaeni (2016) pada pekerja gamping yang mendapatkan nilai koefisiensi kontingensi sebesar 0,55 yang berarti ada hubungan antara APD (masker) dengan status faal paru termasuk kategori ringan. Pekerja yang tidak pernah atau jarang menggunakan masker saat bekerja memiliki risiko 3,5 kali lebih 
tinggi terhadap gangguan faal paru dibanding dengan pekerja yang selalu menggunakan masker saat bekerja ${ }^{5}$. Menurut teori yang dikemukakan oleh Moray IF, Nadel MB bahwa pemakaian masker oleh pekerja industri yang udaranya banyak mengandung debu merupakan upaya untuk mengurangi masuknya partikel debu kedalam saluran pernafasan $^{9}$. Dengan menggunakan masker diharapkan pekerja terlindungi dari kemungkinan terjadinya gangguan pernafasan akibat terpapar udara dengan kadar debu yang tinggi. Kebiasaan menggunakan masker yang baik merupakan cara aman bagi pekerja yang berada di lingkungaan kerja berdebu untuk melindungi kesehatan .

Berdasarkan data dari hasil penelitian ini didapatkan 286 responden (100\%) tidak memiliki riwayat penyakit pada saluran pernapasan sebelumnya karena pekerja yang pernah terdiagnosis penyakit saluran pernapasan masuk dalam kriteria eksklusi. Sedangkan pada variabel riwayat pekerjaan sebelumnya didapatkan bahwa mayoritas pekerja pada PT "X" Malang tidak pernah bekerja di bidang industri sebelumnya sejumlah 238 orang (83\%) dan 48 orang (17\%) lainnya pernah bekerja di bidang industri sebelumnya diantaranya pabrik rokok/tembakau, industri bangunan, dll.

Pada hasil analisis variabel riwayat pekerjaan sebelumnya menunjukkan adanya hubungan yang signifikan antara riwayat pekerjaan sebelumnya di bidang industri dengan faal paru. Pekerja yang pernah bekerja di bidang industri sebelumnya memiliki risiko terjadi gangguan faal paru sebesar 2,5 kali lebih tinggi dari pekerja yang tidak bekerja dibidang industri sebelumnya. Hal ini sesuai dengan teori yang menyatakan seseorang yang sudah pernah bekerja di lingkungan yang terpapar oleh debu industri kemungkinan besar memiliki gangguan faal paru dengan atau tanpa menimbulkan gejala ${ }^{5}$

Pada variabel pekerjaan lain di bidang industri yang dimiliki pekerja didapatkan mayoritas pekerja pada PT "X" Malang tidak memiliki pekerjaan sampingan di bidang industri selain di PT "X" Malang terdapat sejumlah 276 orang $(96,5 \%)$ dan yang memiliki pekerjaan sampingan sejumlah 10 orang $(3,5 \%)$ diantaranya tukang bangunan, tukang parkir, pabrik plastik dan pabrik karton.

Berdasarkan data dari hasil penelitian analisis univariat bahwa faal paru diklasifikasikan menjadi 3 kategori yaitu, normal, restriktif dan obstruktif. Pada 286 responden yang bekerja di PT "X" IBM Malang terdapat sejumlah 84 responden (29\%) memiliki gambaran faal paru yang normal. Sejumlah 202 responden $(71 \%)$ terdapat gangguan pada faal paru diantaranya, 194 pekerja $(68 \%)$ mengalami restriktif dan 8 pekerja (3\%) mengalami obstruktif. Gangguan restriktif merupakan gangguan paru yang menyebabkan kekakuan paru sehingga membatasi 
pengembangan paru-paru. Gangguan ini sangat mempengaruhi kemampuan untuk menghirup udara (inspirasi) seseorang ${ }^{16}$. Para pekerja yang mengalami gangguan ini akan sulit untuk menghirup oksigen dari udara luar dan kondisi ini akan diperparah jika udara yang dihirup mengandung debu yang akan masuk ke dalam paru-paru dan mengendap disana ${ }^{16}$.

Keadaan ini menunjukkan adanya gangguan faal paru yang menyebabkan penurunan FVC dan FEV1. Gangguan faal paru berupa restriktif memiliki keterbatasan ekspansi paru, baik karena perubahan parenkim paru maupun karena penyakit pada pleura dan dinding dada. Tanda-tandanya adalah penurunan kapasitas vital dan volume paru istirahat yang kecil, tetapi resistensi jalan napas (berhubungan dengan volume paru) tidak meningkat ${ }^{16}$.

\section{KESIMPULAN}

1. Pada variabel lingkungan kerja didapatkan kondisi lingkungan kerja yang memiliki debu cukup tebal, namun pada PT "X" Malang memiliki ventilasi ruang kerja cukup baik. Sehingga sesuai dengan hasil uji statistik faktor lingkungan kerja pada pekerja industri papan semen rata di PT "X" Malang tidak terdapat hubungan yang signifikan dengan faal paru pekerja.

2. Variabel karakteristik pekerja pada pekerja industri papan semen rata di PT "X" Malang yang mempengaruhi faal paru pekerja adalah status gizi, kebiasaan olahraga, kebiasaan merokok, penggunaan APD (masker) dan riwayat pekerjaan sebelumnya di bidang industri.

3. Gambaran faal paru pekerja industri papan semen rata di PT " $\mathrm{X}$ " Malang didapatkan dari 286 responden penelitian yang mengalami gangguan faal paru sebanyak 194 orang (68\%) dengan kategori restriktif dan 8 orang (3\%) dengan kategori obstruktif sedangkan 84 orang (29\%) tidak ada gangguan faal paru atau normal.

\section{SARAN}

1. Hasil penelitian ini dapat dijadikan sebagai tambahan informasi pengetahuan bagi mahasiswa Fakultas Kedokteran UMM angkatan 2014

2. Hasil penelitian ini diharapkan dapat menambah pengetahuan dan pemahaman di institusi pendidikan serta acuan rujukan bagi penelitian mengenai analisis lingkungan kerja dan karakteristik pekerja terhadap faal paru pekerja industri papan semen rata.

3. Hasil penelitian ini diharapkan dapat menambah pengetahuan dan pemahaman bagi pekerja dan perusahaan industri dalam pemeliharaan keselamatan kerja.

4. 


\section{Daftar Pustaka}

1. Sholihah M, Tualeka AR, 2015, Studi Faal Paru dan Kebiasaan Merokok Pada Pekerja yang Terpapar Debu Pada Perusahaan Konstruksi di Surabaya, The Indonesian Journal of Occupational Safety and Health, 1-10.

2. Anies, 2005, Penyakit Akibat Kerja, PT Elex Media Komputindo, Jakarta.

3. Yulaekah S, 2007, Paparan Debu Terhirup dan Gangguan Fungsi Paru pada Pekerja Industri Batu Kapur, Fakultas Kedokteran Universitas Diponegoro, Semarang

4. Mila S, 2006, Hubungan Antara Masa Kerja, Pemakaian APD Pernapasan (Masker) pada Tenaga Kerja Pengamplasan dengan Kapasitas Fungsi Paru PT Ascent House Pecangaan Jepara, Fakultas Kedokteran Universitas Negeri Semarang.

5. Suma'mur P, 2013, Higiene Perusahaan dan Kesehatan Kerja (HIPERKES), Agung Seto, Jakarta.

6. Budiono I, 2007, Faktor Resiko Gangguan Fungsi Paru pada Pekerja Pengecatan Mobil, Fakultas Kedokteran Universitas Diponegoro, Semarang.

7. Profil PT "X” Malang tahun 2012

8. Thamrin TM, Akhadi M, 2004, Dampak Radiologis Pelepasan Serat Asbes, Puslitbang Keselamatan Radiasi dan Biomedika Nuklir, Jakarta.

9. Khumaidah, 2009, Analisis faktor-faktor yang berhubungan dengan gangguan fungsi paru pada pekerja mebel PT Kota Jati Furnindo Desa Suwawal Kecamatan Mlonggo Kabupaten Jepara, Fakultas Kedokteran Universitas Diponegoro, Semarang.

10. Anugrah Y, 2013, Faktor - Faktor yang Berhubungan dengan Kapasitas Vital Paru Pada Pekerja Penggilingan Divisi Batu Putih, Fakultas Kedokteran Universitas Negeri Semarang.

11. Guyton, Hall, 2016, Buku Ajar Fisiologi Kedokteran sub bab Ventilasi Paru, edisi 12, penerjemah M. D. Tanzil, Saunders Elsevier, Jakarta.

12. Eva K, 2013, Faktor yang Berhubungan dengan Kapasitas Vital Paru, Fakultas Ilmu Kesehatan Universitas Negeri Semarang.

13. Rasyid AH, 2013, Faktor yang Berhubungan dengan Kapasitas Vital Paru Pada Pekerja di Industri Percetakan Mega Mall Ciputat, Fakultas Kedokteran UIN, Jakarta.

14. Salawati L, 2016, Penyakit Akibat Kerja oleh Karena Pajanan Serat Asbes, Universitas Syiah Kuala, Aceh.

15. Suyono J, 2001, Deteksi Dini Penyakit Akibat Kerja, EGC, Jakarta.

16. Price S, Wilson L, 2006, Patofisiologi : Konsep
Klinis Proses-Proses Penyakit bab Gangguan Sistem Respirasi, edisi 6, Volume 2, EGC, Jakarta. 